\title{
Progress and challenges in eliminating iodine deficiency in Ethiopia: a systematic review
}

\author{
Tirhas M. Gebretsadikan and Aron M. Troen *(D)
}

\begin{abstract}
Background: lodine deficiency disorders (IDD) and their attendant effects on human development, perinatal mortality and intellectual dysfunction are a major nutrition and public health problem worldwide, with Ethiopia counted among the top iodine-deficient countries. Despite the passing of new legislation in 2011 under the National Nutrition Programme and subsequent increase in the availability of iodized salt, the eradication of IDD in Ethiopia remains a significant challenge. This paper critically reviews the recent published data on iodine-status in Ethiopia as a basis for formulating future research and policy initiatives.

Methods: We performed a structural search for IDD studies in Ethiopia for all population groups published after the year 2000 .

Results: Twenty four studies reported national and regional data giving a national total goiter rate above $35.8 \%$ in women, with rates close to $60 \%$ in four regional states, and an estimated prevalence of IDD ranging from 0.4 to $66.3 \%$ depending on region. The prevalence of goiter in children was $35 \%$, but was as high as $71 \%$ in the South Nations Nationalities and Peoples Region. The problem persists despite the widespread availability of iodized salt.

Conclusions: Eradicating IDD in Ethiopia will require concerted efforts including the close evaluation of intervention programs through regular, nation-wide monitoring of IDD and salt-iodization coverage. Salt iodization became mandatory in Ethiopia in 2011 and despite significant progress, the current level of eradicating IDD could be improved. Prospective and controlled intervention studies to evaluate biomarkers of thyroid function and cognitive outcomes will help to monitor and improve eradication efforts. Ascertaining and improving health and development in the most vulnerable populations of women and children is a priority that may be advanced through a greater investment in outreach and education.
\end{abstract}

Keywords: Children, Ethiopia, lodine deficiency, lodine deficiency disorder, Universal salt iodization, Women

\section{Background}

Iodine is an essential micronutrient and necessary component of the thyroid hormones thyroxine (T4) and triiodothyronine (T3), which are necessary for normal growth, development, and metabolism during pregnancy, infancy and throughout life [1]. The ecological availability of iodine

\footnotetext{
* Correspondence: aron.troen@mail.huji.ac.il
}

The Institute of Biochemistry, Food and Nutrition Science; The Robert $\mathrm{H}$. Smith Faculty of Agriculture Food and the Environment, The Hebrew University of Jerusalem Israel, P.O. Box 12, Rehovot 76100, Israel from soil and water for incorporation by the plants and animal that are used for food are key determinants of human iodine intake [2]. In iodine poor regions of the world, interventions are necessary to prevent endemic iodine deficiency disorders.

In healthy humans, the adult thyroid gland contains about 15-20 mg of iodine [3] used to produce the hormones needed for normal neuronal migration and myelination of the brain during fetal and early postnatal life [4]. Intake of iodine below the minimum requirement causes iodine deficiency (ID), which if chronic leads to subsequent iodine deficiency disorders (IDD) [5]. IDD is a serious health problem whose effects are most severe 
during pregnancy and childhood. During pregnancy it can result in stillbirth, spontaneous abortion, congenital abnormalities and intellectual dysfunction including cretinism and irreversible physical disabilities [6]. Among children it is associated with high mortality and causes intellectual dysfunction and brain damage as a result of low thyroid hormone production and subsequent impairment of brain development [7]. Circulating thyroid hormone levels are known to be low in infants and women in areas affected by moderate to severe ID [4]. According to the 2011 estimate of the Iodine Global Network (formerly the International Council for the Control of IDD) [8], nearly two billion individuals have insufficient iodine intake worldwide, including one-third of all school-age children. ID is a public health problem in 32 countries, especially developing countries, like Ethiopia [9].

The majority of the Ethiopian population has suffered from ID and related public health problems for the last six decades. In 2011, Ethiopia was among the most iodine deficient countries in the world [10]. About 12 million school age children were thought to live with inadequate iodine, and a total of 66 million people, or $62 \%$ of Ethiopia's population, are vulnerable to the risk of IDD [8]. Prevalent ID was reflected in a rate of cretinism of one per thousand, an estimated 50,000 IDD related peri-natal deaths annually, and a rise in the overall prevalence of goiter from $26 \%$ in 1980 [11] to $40 \%$ in 2009 [12]. The prevalence of goiter in children varied from $<15$ to $>30 \%$ in low and high goiterendemic regions, respectively [13]. These figures reflect the fact that the median national urinary iodine excretion (UIE) concentration $(24.5 \mu \mathrm{g} / \mathrm{L})$ [14] is well below the $\mathrm{WHO} /$ UNICEF/ICCIDD cut-off point $(100 \mu \mathrm{g} / \mathrm{L})$ for adequate iodine intake in the population, leading to severe (UIE $<20 \mu \mathrm{g} / \mathrm{L})$ to moderate $(20.1<\mathrm{UIE}<50 \mu \mathrm{g} / \mathrm{L})$ ID in the population.

Despite the government's implementation in 2011 of a long-term plan to eradicate ID through salt iodization, the problem reportedly persists [15] and data concerning sub groups of the population and locations suffering from ID are incomplete. We therefore undertook a systematic review of published peer-reviewed data in order to provide a critical update on iodine status and deficiency in Ethiopia. The review covered studies published between the years 2000-2015 to assess the available data on IDD before and after iodized salt became widely available in 2011. We were particularly interested in ascertaining the national and regional prevalence of ID in the most vulnerable groups (mothers and their children), and in evaluating the impact that salt iodization has had to date.

\section{Methods}

Our review aimed to address the following major research questions
(1) What is the status of iodine availability and consumption in the country?

(2) What are the effects of inadequate iodine in the most vulnerable groups?

(3)How prevalent is ID in different regions of the country?

(4) What are the subsequent consequences of ID?

(5) What solutions have been implemented or proposed for eradicating ID?

(6) To what degree has the population been made aware of the importance of iodine and the serious effects of iodine deficiency?

Search terms were set in February 2014, and the most recent search was done in March 2015. The search terms included all publications with the terms "Ethiopia" and "iodine intake" as well as more specific queries with phrases to identify studies on the prevalence of ID in women and children; iodine deficiency disorder (IDD); causes of IDD; effects of IDD; IDD in Ethiopia, IDD in pregnant or lactating mothers; IDD in children; IDD indicators; urinary iodine concentration and thyroid grade (goiter rate); iodized salt; household availability: USI in Ethiopia; distribution of USI; iodized salt consumption; concentration of iodine in salt at producer, retailer and household level. Using these terms, searches were performed in PubMed and Google scholar search engines for articles, reviews, reports, e-books and workshops proceedings. The search was limited to studies published between early 2000 and March 2015. Data extraction parameters were set first, including study design, regions covered, population groups, ID indicator variables and overall findings. The two reviewers then extracted and tabulated the data from all of the retrieved publications and checked agreement between them prior to writing the review.

\section{Results and discussion}

Our search identified a total of 33 abstracts, nine of which were excluded because the information was outdated (published before 2000) leaving 24 studies. All but one of the remaining studies had a cross-sectional design. The remaining study was a retrospective cohort design and no reports were found of controlled interventions. Because the number of research reports on Ethiopia was relatively small, they were all included in the review without additional selection for quality of the evidence (Fig. 1). They were classified as pertaining to the topics shown in Table 1, with some studies touching on more than one topic:

\section{Regional studies of ID in Ethiopia are incomplete}

To date, nationally representative data on ID in Ethiopia are limited. Of the publications reviewed here, only three 


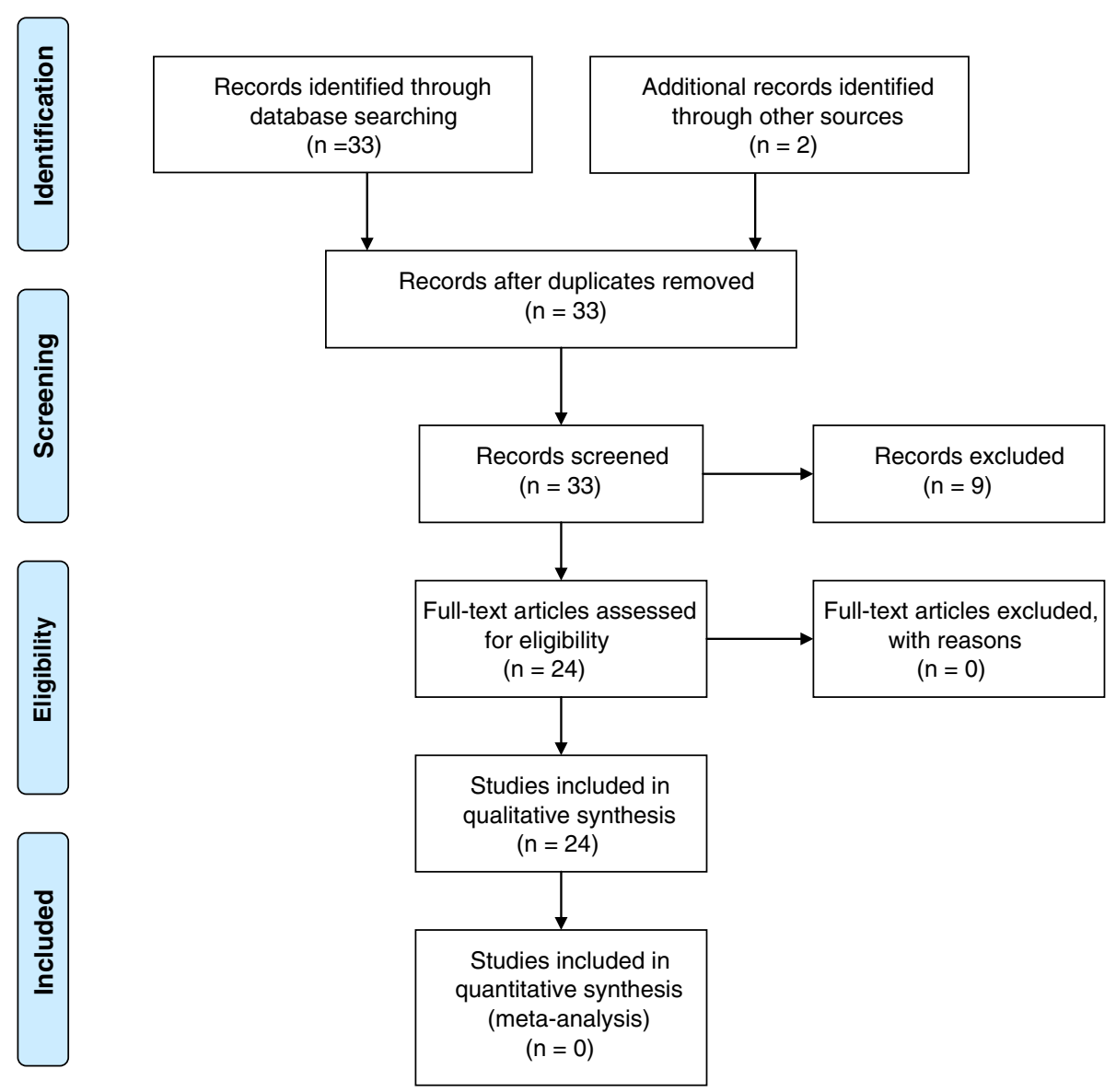

Fig. 1 PRISMA flowchart diagram

reported on ID and its effects in children and women of child-bearing age at the national level, two made before $[13,16]$ and one after the implementation of Universal Salt Iodization in 2011 [17]. The remaining publications focused on ID among the most vulnerable groups in only six of Ethiopia's ten regional states (Fig. 2). For example, in Oromia, the largest populated region, seven studies investigated iodine level in food and water, and ID prevalence in children and women (Table 2). Only few areas of Jimma zone [7, 11, 18], Arsi zone [19], Bale zone [20] and Haramaya district [21] were covered, while other zones and districts have no information. Southern Nation Nationalities and Peoples were targeted with three independent studies of zones and districts such as Gamo Gofa [19], Kafa [22], Sidama [23-25], Hawasa [26] and Sodo $[27,28]$. Four reports on the Amhara region targeted areas in Shoa zone [19], Bahir Dar town [29], Wombera and Burie districts [30], and Lay Armachiho district [31]. Benshangul Gumuz region (Metekel zone) [32] and Tigray region (Neksege subdistrict) [33] had each of a single independent report. Interestingly, studies on iodine contents at production, retailer and household levels was conducted nationally and regionally in Amhara, Tigray and
Afar regions [5, 17], but not elsewhere. There was also a single cohort study (with retrospective analysis) in Addis Ababa city focused on the histopathologic patterns of thyroid disease and their relationship with age and sex [34]. In contrast, no independent studies were reported on Gambella, Harari and Somali regions, and a chartered city (Dire Dawa).

\section{ID prevalence in Ethiopian women}

Although iodine is essential for all population groups, women require high amounts during pregnancy because of an increase in maternal thyroxine (T4) production and loss of iodide through the kidneys due to the renal clearance of iodide [9]. Urinary iodine concentration (UIC) and thyroid volume (goiter rate (GR)) can be used to assess iodine intake below the recommended levels in women [35]. Interestingly, GR also serves as an indicator of ID prevalence [36]. Despite the fact that ID has been a serious health problem for the Ethiopian population for a long period, few scientific studies have been carried out nationwide in women to assess the prevalence of ID. Notably, a national cross-sectional community based survey reported in 2007 on the severity of goiter among 
Table 1 Number of publications identified by topic

\begin{tabular}{|c|c|c|}
\hline Study topics & $\begin{array}{l}\text { Number of } \\
\text { publications }\end{array}$ & References \\
\hline \multicolumn{3}{|l|}{ Population group } \\
\hline -Women & 5 & $\begin{array}{l}{[13,18,21,24,} \\
25]\end{array}$ \\
\hline - Children & 10 & $\begin{array}{l}{[7,16,19,22} \\
26-29,31,32]\end{array}$ \\
\hline - Women \& Children & 3 & {$[23,30,47]$} \\
\hline - Population & 2 & {$[11,33]$} \\
\hline lodine Sources & 4 & {$[5,11,17,20]$} \\
\hline \multicolumn{3}{|l|}{ Study regions ${ }^{b}$} \\
\hline - Nationwide & 3 & {$[13,16,17]$} \\
\hline - Tigray & 2 & {$[5,33]$} \\
\hline - Amhara & 3 & [29-31] \\
\hline - Oromia & 5 & {$[7,11,18,20,21]$} \\
\hline - Addis Ababa & 1 & {$[34]$} \\
\hline $\begin{array}{l}\text { - Southern Nations Nationalities and } \\
\text { Peoples Region (SNNPR) }\end{array}$ & 7 & [22-28] \\
\hline - Benshangul-Gumuz & 1 & {$[32]$} \\
\hline - More than two regions & 2 & {$[19,47]$} \\
\hline \multicolumn{3}{|l|}{ ID Aggravating factors } \\
\hline - Cassava intake & 2 & {$[24,47]$} \\
\hline
\end{tabular}

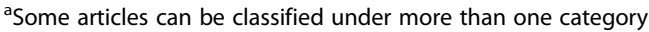

${ }^{\mathrm{b}}$ Some studies include data on more than one region

women 15 to 49 using GR parameters such as total GR (TGR) [13]. TGR was found in above $30 \%$ of women in SNNPR, Benshangul Gumuz, Tigray and Oromia with a maximum of nearly $60 \%$ in SNNPR regional state indicating severe ID in this region. The prevalence of goiter in the rest of the regional states ranged from 5 to $29.9 \%$, except for Gambella with a rate of $1.4 \%$, that is, a mild to moderate degree of ID [35].

Several studies indicate that ID persits among Ethiopian women despite salt iodization in 2011. A high TGR of $30.1 \%$ among mothers was reported for the Burie and Womberma districts in 2014 [30]. In the same year $88.9 \%$ of pregnant women visiting Jimma University Specialized Hospital for antenatal care were iodine deficient with a median urinary iodine (MUI) of $48 \mu \mathrm{g} / \mathrm{L}$ [18]. A comparable study from 2014 found $82.8 \%$ of pregnant women in the Haramaya district to be deficient with a MUI of $58.1 \mu \mathrm{g} / \mathrm{L}$ [21]. Similarly, a study from 2013 among non-pregnant women living in rural communities of Sidama zone, found that $96.5 \%$ had UIC below $100 \mu \mathrm{g} / \mathrm{L}$ with a MUI of $37.2 \mu \mathrm{g} / \mathrm{L}$ [24]. Of these women, $22.8 \%$ were severely ID, $46.5 \%$ were moderately ID, and $27.2 \%$ were mildly ID and only $3.5 \%$ had adequate iodine (UIC $>100 \mu \mathrm{g} / \mathrm{L}$ ) [24]. Participants of this study had $15.9 \%$ TGR in which 1.5 and $14.4 \%$ were visible and palpable goiter, respectively [24]. Despite the severity of these findings, such figures show a reduction in ID following salt iodization compared with previous report from the same area published by Bogale et al. in 2009 [23], who found $99 \%$ of mothers to have UIC below $20 \mu \mathrm{g} / \mathrm{L}$ and an $85 \%$ prevalence of goiter.

There are only limited reports on the health consequences of goiter in women. A review of different countries worldwide showed that reproductive failure has been related to goiter and goiter endemicity [14]. A recent survey in the southern part of Ethiopia found that cognitive function, particularly of short term memory and visual processing, were strongly associated between women with ID and their biological children, a finding that suggests infants are affected by their mother's ID [23]. Although these reports highlight the crucial importance of targeting interventions to women, they are insufficient for the design of effective programs. To support such efforts, research is urgently needed on ID prevalence among Ethiopian women in all regions with assessment of short and long-term health, social and economic impacts.

\section{ID prevalence in Ethiopian children}

The severity of ID in the general population is clearly indicated by its appearance among school-age children. The national cross-sectional study from before iodization (2007) demonstrated a high prevalence of ID among 10,965 children aged $6-12$ years as indicated by both low UIC and high TGR [16]. Based on UIC values, nearly $46 \%$ of children had severe ID ( $2 \mu \mathrm{g} / \mathrm{dL}$ or less), $23 \%$ were moderately iodine deficient $(2.01-5.00 \mu \mathrm{g} / \mathrm{dL}), 15 \%$ were mildly deficient $(5.01-10.00 \mu \mathrm{g} / \mathrm{dL})$ and only $17 \%$ were within the normal range $(>100 \mu \mathrm{g} / \mathrm{dL})$. Using the prevalence of goiter as an indicator, the survey recorded the highest TGR in the SNNPR region (56.2 \%), followed by Oromia (42.0\%), Benshangul-Gumuz (40.5 \%), Amhara (29.1\%), and Tigray (21.9\%) [16]. These results showed severe ID with over $30 \%$ of TGR in three regional states, whereas two other regions had moderate ID with between 20.0 and $29.9 \%$. The TGR in the rest of the regional states ranged from about 5-20 \%, indicating mild ID. Harari had the lowest TGR (4.7\%), and is considered the only normal region. Overall, Ethiopia had 39.9 \% TGR with rates of $27.7 \%$ for palpable and $12.2 \%$ for visible goiter, with about 4 million children affected by goiter throughout the country except for Gambella regional state [16].

Following salt iodization, prevalent ID appears to have improved somewhat and yet it persists as a significant problem among children. In a regional study from 2012 by Girma et al. [26] the median UIC of school children in Hawassa town (SNNP region) was $34.2 \mu \mathrm{g} / \mathrm{L}$ ranging from 1 to $177 \mu \mathrm{g} / \mathrm{L}$. The distribution of urinary iodine showed that $18.9 \%$ children had severe ID ( $<20 \mu \mathrm{g} / \mathrm{L}$ UIC), $63.2 \%$ had moderate ID (20-49 $\mu \mathrm{g} / \mathrm{L}$ UIC) and $16 \%$ had mild ID 


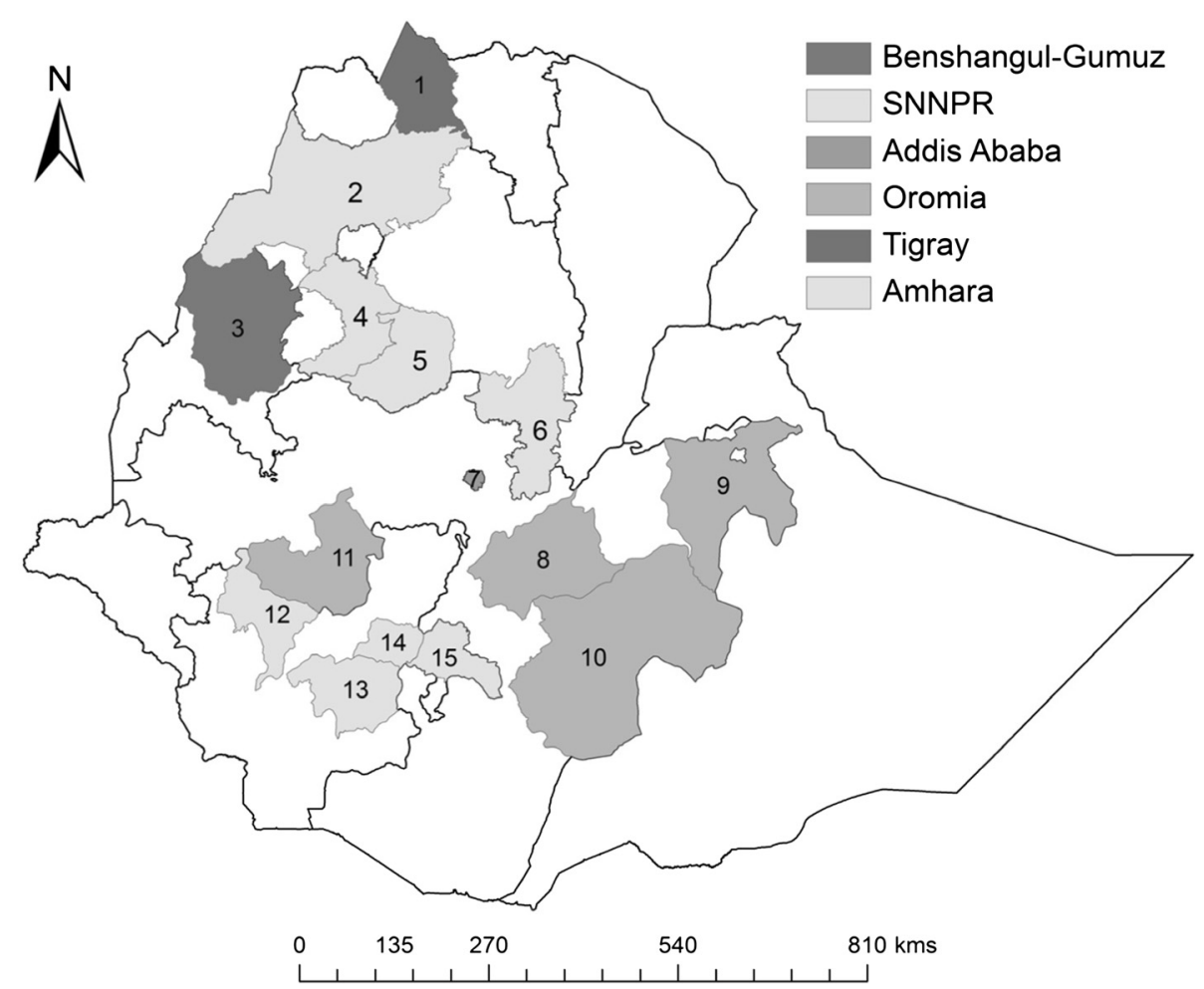

Fig. 2 The Map identifies locales where ID has been studied in five regions and a charter city. These include Tigray region, (1) Northwest zone (Neksege subdistrict); Amhara region, (2) North Gondar zone (Lay Armachiho district), (4) West Gojam zone (Bahir Dar city), (5) East Gojam zone (Burie and Wombera), (6) Shoa zone; in Benshangul-Gumuz, (3) Metekel zone; (7) Addis Ababa city; in Oromia region, (8) Arsi zone, (9) East Harergie zone (Haramaya), (10) Bale zone, (11) Jimma zone; in SNNPR, (12) Kafa zone, (13) Gamo Gofa zone, (14) Wolayita zone (Sodo), (15) Sidama zone (Sidama and Hawasa)

(50-99 $\mu \mathrm{g} / \mathrm{L}$ UIC). In this study, TGR was $13.6 \%$, well above the $5 \%$ cut-off highlighting ID as a public health concern. Moreover, GR was associated with age, so that older children (8-9 years) were more goiterous than younger children (age 7) (17.6\% vs. $5.6 \%$, respectively) [26]. Although the prevalence of ID in this report is lower compared with the earlier community-based survey data from SNNP region [16], this may partly reflect the fact that Hawassa town is urban and the distribution of iodized salt and awareness of its importance may be better in urban than in rural communities. In another study from the same year, the median urinary iodine value was measured at $56 \mu \mathrm{g} / \mathrm{L}$ for both male and female children in Jimma, but taken separately; females $(54 \mu \mathrm{g} / \mathrm{L})$ had lower values than males $(74 \mu \mathrm{g} / \mathrm{L})$ [7]. Higher goiter rates in female than in male children have also been reported in other studies nationwide [16] and in Kafa which is found in SNNPR [22].

ID in children has also been assessed recently in greater detail, using goiter grades and thyroid stimulating hormone (TSH). A report from 2014 found a high prevalence of TG among school children from the Metekel region found a GR of $39.5 \%$ (grade $1=31.5 \%$, grade $2=8 \%$ ) and a median UIC of only $39.9 \mu \mathrm{g} / \mathrm{L}$ [32]. The median UIC of $39.9 \mu \mathrm{g} / \mathrm{L}$ in this study was indicative of only moderate ID but the GR is indicative of severe ID. On the basis of TSH values, the prevalence of thyroid dysfunction was $45.95 \%$ of which 18.92 and $27.03 \%$ had elevated and suppressed TSH levels, respectively. A comparable prevalence of goiter (37.6 \%) was found in the Lay Armachiho district in 2014 with $28.5 \%$ having a grade 1 and $9.1 \%$ having a grade 2 goiter [31].

Interestingly, the association between goiter and cognitive function has been studied on 5-year-old children in rural Sidama, prior to universal salt iodization in 2009 [23]. The results revealed a highly significant correlation $(r=0.39, p=0.001)$ between goiter and short-term memory among the children studied, but no significant differences were detected in other cognitive tests between children with goiter and without goiter. In line with this, a study by Wolka et al. from 2014 observed that children with goiter were 1.8 times more likely to have low academic achievement than those who did not have goiter (adjusted OR $=1.8$; $95 \%$ CI 1.2, 2.5) [27]. Moreover, goiter was associated with both absenteeism and a higher prevalence of below-average academic scores $(57.0 \%$ of children with goiter were below average vs. $41.3 \%$ without goiter, $p<0.01)$. These findings, implying that ID reduces learning ability and school performance, underscore the importance of fostering programs to eradicate 
Table 2 Design and major findings of studies on iodine nutrition and IDD in Ethiopia published between the years 2000-2015

\begin{tabular}{|c|c|c|c|c|}
\hline Author, year & Study design & Study region & $\begin{array}{l}\text { Number of } \\
\text { participants (n) }\end{array}$ & Outcome variables \\
\hline $\begin{array}{l}\text { Abuye and Urga } \\
2000[19]\end{array}$ & $\begin{array}{l}\text { Cross } \\
\text { sectional }\end{array}$ & $\begin{array}{l}\text { Four locations: } \\
\text { Amhara (Shoa) } \\
\text { Oromia (Jimma \& } \\
\text { Arsi) SNNPR (Gamo } \\
\text { Gofa) }\end{array}$ & $\begin{array}{l}\text { Elementary school } \\
\text { children (2485) }\end{array}$ & $\begin{array}{l}\text { Goiter rate, UIC, iodine concentration in } \\
\text { water, common foods of plant origin } \\
\text { and milk, bacterial contamination of } \\
\text { drinking water }\end{array}$ \\
\hline $\begin{array}{l}\text { Takele et al. } \\
2003[11]\end{array}$ & $\begin{array}{l}\text { Cross } \\
\text { sectional }\end{array}$ & $\begin{array}{l}\text { Oromia region: } \\
\text { Shebe town -Jimma } \\
\text { zone, Southwest }\end{array}$ & $\begin{array}{l}\text { Retail shops and } \\
\text { households (332) }\end{array}$ & $\begin{array}{l}\text { lodine content of household and shop } \\
\text { salt }\end{array}$ \\
\hline $\begin{array}{l}\text { Tsegaye and } \\
\text { Ergete } 2004[34]\end{array}$ & $\begin{array}{l}\text { Retrospective } \\
\text { analysis } \\
\text { (cohort study) }\end{array}$ & $\begin{array}{l}\text { Tikur Anbessa } \\
\text { teaching and referral } \\
\text { hospital, Addis } \\
\text { Ababa }\end{array}$ & $\begin{array}{l}\text { Patients with } \\
\text { thyroid disease } \\
\text { (780) }\end{array}$ & $\begin{array}{l}\text { Histopathologic patterns of thyroid } \\
\text { disease and their relationship with age } \\
\text { and sex over a five year period. }\end{array}$ \\
\hline $\begin{array}{l}\text { Berhanu et al. } \\
2004 \text { [22] }\end{array}$ & $\begin{array}{l}\text { Cross } \\
\text { sectional }\end{array}$ & $\begin{array}{l}\text { SNNPR region: Kafa } \\
\text { Zone, Southwestern }\end{array}$ & $\begin{array}{l}\text { Students, aged 6- } \\
15 \text { years (1044) }\end{array}$ & Goiter rate \\
\hline $\begin{array}{l}\text { Kidane and } \\
\text { Woldegebriel } \\
2006 \text { [33] }\end{array}$ & $\begin{array}{l}\text { Cross } \\
\text { sectional }\end{array}$ & $\begin{array}{l}\text { Tigray region: } \\
\text { Neksege Sub District } \\
\text { Northern }\end{array}$ & $\begin{array}{l}\text { The entire } \\
\text { population (946) }\end{array}$ & Total goiter rate \\
\hline $\begin{array}{l}\text { Abuye et al. } \\
2007[16]\end{array}$ & $\begin{array}{l}\text { Cross } \\
\text { sectional }\end{array}$ & National level & $\begin{array}{l}\text { Children aged 6- } \\
12 \text { years }(10,965)\end{array}$ & Total goiter rate and UIC \\
\hline $\begin{array}{l}\text { Abuye and } \\
\text { Berhane } 2007 \\
{[13]}\end{array}$ & $\begin{array}{l}\text { Cross } \\
\text { sectional }\end{array}$ & National level & $\begin{array}{l}\text { women in child } \\
\text { bearing, 15- } \\
49 \text { years old } \\
\text { (10998) }\end{array}$ & Total goiter rate \\
\hline $\begin{array}{l}\text { Bezabih et al. } \\
2007 \text { [29] }\end{array}$ & $\begin{array}{l}\text { Cross } \\
\text { sectional }\end{array}$ & $\begin{array}{l}\text { Amhara region: Bahir } \\
\text { Dar town, northwest }\end{array}$ & $\begin{array}{l}\text { Primary school } \\
\text { children (386) }\end{array}$ & UIC \\
\hline $\begin{array}{l}\text { Abuye et al. } \\
2008[47]\end{array}$ & $\begin{array}{l}\text { Cross } \\
\text { sectional }\end{array}$ & $\begin{array}{l}\text { Five regional states: } \\
\text { Amhara, Oromia, } \\
\text { Tigray, SNNPR \& } \\
\text { Benshangul-Gumuz }\end{array}$ & $\begin{array}{l}\text { Children and their } \\
\text { biological mothers } \\
\text { (6960) }\end{array}$ & Goiter, UIC and cassava consumption \\
\hline
\end{tabular}

Major findings

$-53.3 \%$ gross goiter prevalence

- 0.33-0.70 $\mu \mathrm{mol} / \mathrm{L}$ UIE rate

The iodine content:

0-75 ppm in household salt

$0.1-75$ ppm in shop samples salt

- Higher non-neoplastic (79 \%) than that of neoplastic (21\%)

- Nodular colloid goiter recorded in $76.9 \%$ cases

- Adenoma, carcinoma and thyroiditis accounted for $12.8 \%, 648.2 \%$ and 16 $2.1 \%$ cases, respectively.

- $85.7 \%$ thyroid diseases in the age group of 20-59 years

$27.4 \%$ goiter prevalence

$71.4 \%$ community goiter prevalence with $59.5 \%$ in males and $80.2 \%$ in females.

- $39.9 \%$ total goiter prevalence

- $2.45 \mu \mathrm{g} / \mathrm{dL}$ median UIE

$35.8 \%$ total goiter prevalence

$58.8 \mathrm{mg} / \mathrm{L}$ median UIE

- Cassava consumption and high altitude were risk factors for IDD

- Goitre affected those who frequently consume cassava significantly than who did not

Bogale et al. Cross 2009 [23] sectional

SNNPR region: Rural Sidama, Southern

Children and their biological mothers (100)

Goiter grade, UIC, Raven's CPM and

- $85 \%$ Goiter prevalence in cognitive tests from the Kaufman ABC-\| the mothers and $33 \%$ in children

. $1 \mu \mathrm{g} / \mathrm{L}$ median UIC for both mothers and children

- short term memory correlated to child goiter,

- cognition also associated with child UIE
Concentration of iodine in sampled salts the sampled salts decreased in between production site and the consumers

- $13.6 \%$ total goiter rate 
Table 2 Design and major findings of studies on iodine nutrition and IDD in Ethiopia published between the years 2000-2015 (Continued)

\begin{tabular}{|c|c|c|c|}
\hline $\begin{array}{l}\text { Girma et al. } \\
2012 \text { [26] }\end{array}$ & $\begin{array}{l}\text { Cross } \\
\text { sectional }\end{array}$ & $\begin{array}{l}\text { SNNPR region: } \\
\text { Hawassa town }\end{array}$ & $\begin{array}{l}\text { School children } \\
\text { aged 7-9 years } \\
(116)\end{array}$ \\
\hline $\begin{array}{l}\text { Mezgebu et al. } \\
2012 \text { [7] }\end{array}$ & $\begin{array}{l}\text { Cross } \\
\text { sectional }\end{array}$ & $\begin{array}{l}\text { Oromia region: } \\
\text { Shebe Senbo District, } \\
\text { Jimma zone }\end{array}$ & $\begin{array}{l}\text { Children 6-12 } \\
\text { years (389) }\end{array}$ \\
\hline $\begin{array}{l}\text { Gebreegziabher } \\
\text { t al. } 2013 \text { [24] }\end{array}$ & $\begin{array}{l}\text { Cross } \\
\text { sectional }\end{array}$ & $\begin{array}{l}\text { SNNPR region: rural } \\
\text { communities of } \\
\text { Sidama Zone, } \\
\text { southern }\end{array}$ & $\begin{array}{l}\text { Non-pregnant } \\
\text { women (202) }\end{array}$ \\
\hline $\begin{array}{l}\text { Ersino et al. } \\
2013 \text { [25] }\end{array}$ & $\begin{array}{l}\text { Cross } \\
\text { sectional }\end{array}$ & $\begin{array}{l}\text { SNNPR region: rural } \\
\text { Sidama Zone, } \\
\text { southern }\end{array}$ & $\begin{array}{l}\text { Pregnant } \\
\text { women (172) }\end{array}$ \\
\hline
\end{tabular}

$\begin{array}{lll}\text { Duressa et al. } & \text { Comparative } & \text { Oromia region: } \\ 2014[20] & \text { analysis } & \text { Horaboka, Mio and } \\ & & \text { Besaso Kebeles, } \\ & \text { Sinana Werada, Bale } \\ & \text { Zone }\end{array}$

ENMS 2014 [17] Cross sectional

Kebede et al. Cross 2014 [30] sectional

Kedir et al. 2014 Cross [21]
Eastern Ethiopia: Haramaya district
Amhara region: Burie and Womberma districts
Pregnant women (435)
Total goiter rate, Urinary iodine excretion content of iodine in salt
Goiter rate, urinary iodine concentration, • $34.2 \mu \mathrm{g} / \mathrm{L}$ the median UIC dietary patterns and caretaker knowledge of iodine deficiency

urinary iodine concentration, percentage of population with UIC < $20 \mu \mathrm{g} / \mathrm{L}$, percentage of households using iodized salt, iodine content of salt and total goiter rate

Urinary iodine concentration, goiter and dietary intake of the society

lodine content of water, soil, salt and
cereals in the area
cereals in the area

$$
\begin{aligned}
& \text { Rural (150) and } \\
& \text { Urban (250) } \\
& \text { households }
\end{aligned}
$$

Children and their biological mothers (403)

Thyroid size, urinary iodine level determination, household level interview and Focus Group Discussion (FGD)

target groups background, dietary habits, gynecological/obstetric questionnaire and UIC
- low iodine in foods made from grains and consumption of animal source foods

- Limited knowledge about the importance of iodized salt

- $59.1 \%$ total goiter rate

- $564 \mathrm{~g} / \mathrm{L}$ median urinary iodine level

• $71.2 \%$ non-iodinated salt users

- $26.2 \%$ used iodinated salt

. $37.2 \mu \mathrm{g} / \mathrm{L}$ Median UIC

- $15.9 \%$ total goiter rate

- Consumed E. ventricosum, corn and kale frequently

- $15 \mu \mathrm{g} / \mathrm{L}$ Median UIC

. $60 \%$ of the women with < $20 \mu \mathrm{g} / \mathrm{L}$ UIC

- More than $90 \%$ of households not using iodized salt

- Median salt iodine content was almost zero

- $49 \%$ total goiter rate

- lodine concentration level in water below $15 \mu \mathrm{g} / \mathrm{l}$, the world's average drinking

- High in non-farm lands soil and low farm lands soils

- Low in wheat and barley crops

- lodated salt coverage reaches up to $88.8 \%$ and $94.4 \%$ by RTK and iodometric titration respectively

- Only $23.2 \%$ of adequacy (20-40 ppm)

- $54.5 \%$ total goiter rate in school age children

- $30.1 \%$ total goiter rate in biological mothers

- $0.5 \mu \mathrm{g} / \mathrm{dl}$ median urinary iodine

- $1.1 \%$ iodized salt in of the households

- $58.1 \mu \mathrm{g} / \mathrm{L}$ median urinary iodine

- $82.8 \%$ subclinical iodine deficiency in women 
Table 2 Design and major findings of studies on iodine nutrition and IDD in Ethiopia published between the years 2000-2015 (Continued)

\begin{tabular}{|c|c|c|c|c|c|}
\hline \multirow[t]{4}{*}{$\begin{array}{l}\text { Kibatu et al. } \\
2014 \text { [32] }\end{array}$} & \multirow[t]{4}{*}{$\begin{array}{l}\text { Cross } \\
\text { sectional }\end{array}$} & \multirow{4}{*}{$\begin{array}{l}\text { Benshangul-Gumuz } \\
\text { region: Metekel Zone } \\
\text { Northwest }\end{array}$} & \multirow[t]{4}{*}{$\begin{array}{l}\text { Children aged 6- } \\
18 \text { years (200) }\end{array}$} & \multirow[t]{4}{*}{$\begin{array}{l}\text { Total goiter rate, urinary iodine } \\
\text { excretion and TSH level }\end{array}$} & $\begin{array}{l}\text { - } 39.5 \% \text { total goiter } \\
\text { prevalence }\end{array}$ \\
\hline & & & & & $\begin{array}{l}\text { • } 39.9 \mu \mathrm{g} / \mathrm{L} \text { median urinary } \\
\text { iodine }\end{array}$ \\
\hline & & & & & $\begin{array}{l}\text { - } 18.92 \% \text { elevated thyroid } \\
\text { hormones }\end{array}$ \\
\hline & & & & & • $27.03 \%$ suppressed TSH \\
\hline \multirow{2}{*}{$\begin{array}{l}\text { Mesele et al. } \\
2014[31]\end{array}$} & \multirow{2}{*}{$\begin{array}{l}\text { Cross } \\
\text { sectional }\end{array}$} & \multirow{2}{*}{$\begin{array}{l}\text { Amhara region: Lay } \\
\text { Armachiho district, } \\
\text { Northwest }\end{array}$} & \multirow{2}{*}{$\begin{array}{l}\text { Children 6- } \\
12 \text { years (698) }\end{array}$} & \multirow{2}{*}{$\begin{array}{l}\text { the presence/absence of goiter, the } \\
\text { level of iodine in salt }\end{array}$} & - $37.6 \%$ prevalence of goiter \\
\hline & & & & & $\begin{array}{l}\text { - Salt iodine level }(A O R= \\
0.44)\end{array}$ \\
\hline \multirow[t]{2}{*}{$\begin{array}{l}\text { Negeri et al. } \\
2014[18]\end{array}$} & \multirow[t]{2}{*}{$\begin{array}{l}\text { Cross } \\
\text { sectional }\end{array}$} & \multirow{2}{*}{$\begin{array}{l}\text { Oromia region: } \\
\text { Jimma University } \\
\text { Specialized Hospital }\end{array}$} & \multirow[t]{2}{*}{$\begin{array}{l}\text { Pregnant women } \\
(423)\end{array}$} & \multirow[t]{2}{*}{ UIC } & $\begin{array}{l}\text { - } 88.9 \% \text { prevalence of iodine } \\
\text { deficiency }\end{array}$ \\
\hline & & & & & $\begin{array}{l}\text { - } 48 \mu \mathrm{g} / \mathrm{L} \text { median urinary } \\
\text { iodine }\end{array}$ \\
\hline $\begin{array}{l}\text { Wolka et al. } \\
2014[27]\end{array}$ & $\begin{array}{l}\text { Cross } \\
\text { sectional }\end{array}$ & $\begin{array}{l}\text { SNNPR region: Sodo } \\
\text { town, Southern } \\
\text { Ethiopia }\end{array}$ & Children (534) & $\begin{array}{l}\text { Association of goiter with academic } \\
\text { achievement }\end{array}$ & $\begin{array}{l}\text { Goiter linked with low } \\
\text { academic achievement } \\
\text { (adjusted OR51.8; } 95 \% \mathrm{Cl} \\
\text { 1.2, 2.5). }\end{array}$ \\
\hline \multirow[t]{2}{*}{$\begin{array}{l}\text { Wolka et al. } \\
2014 \text { [28] }\end{array}$} & \multirow[t]{2}{*}{$\begin{array}{l}\text { Cross } \\
\text { sectional }\end{array}$} & \multirow[t]{2}{*}{$\begin{array}{l}\text { SNNPR: Sodo Town, } \\
\text { Southern Ethiopia }\end{array}$} & \multirow{2}{*}{$\begin{array}{l}\text { children aged } 6 \text { to } \\
12 \text { years ( } 270 \text { with } \\
\text { goiter and } 264 \\
\text { without goiter) }\end{array}$} & \multirow[t]{2}{*}{$\begin{array}{l}\text { Presence of goiter Association between } \\
\text { goiter and goitrogenic food items }\end{array}$} & $\begin{array}{l}\text { - Drinking river water } \\
\text { positively associated with } \\
\text { goiter presence }\end{array}$ \\
\hline & & & & & $\begin{array}{l}\text { - Cabbage and cassava } \\
\text { consumption increased the } \\
\text { chance of goiter. }\end{array}$ \\
\hline
\end{tabular}

Note: IDD iodine deficiency disorder, SNNPR Southern Nations Nationalities and Peoples Region, UIC urinary iodine concentration, UIE urinary iodine excretion

ID and thereby enhance development, productivity, and economic potential of the state and its citizens.

\section{Intervention strategies}

IDD is considered the most important preventable cause of brain damage worldwide [37]. Universal salt iodization (USI) has been a major focus in the global strategy to eliminate the problem for the last few decades, and the preferred and most effective long-term public health intervention for achieving optimal iodine nutrition in deficient areas [32]. USI is a safe, cost-effective, and sustainable strategy to ensure sufficient intake of iodine by different groups [38]. It is now well recognized and applied in nearly all countries suffering from ID to eliminate IDD. USI involves the iodization of all salts used by human, livestock and food industry. Adequate iodization of salt can deliver iodine in the required amount and sustainable basis to the population [36].

There is good precedent to show that effective USI could ease the problem in Ethiopia. A study from Tanzania, where the prevalence of goiter used to be $25 \%$, showed that within 12 years of initiating USI, $84 \%$ of the population consumes iodized salt, and $94.5 \%$ of 6-12 year old children have normal sized thyroid glands [38]. Similarly, the GR of Chinese schoolchildren affected by mild IDD dropped from 18 to $5-9 \%$ after just 18 months of salt iodization supplement [39]. According to a recent ICCIDD letter [15], African countries such as Burundi, Kenya, Nigeria, Uganda, Tunisia, Namibia, Zimbabwe and Libya have successfully achieved USI, and their coverage of households with iodized salt is more than $90 \%$. Particularly, Nigeria has been certified in 2005 for successful accomplishment of USI (95-98 \%) throughout the country [40] despite remaining of some gaps that need to be filled [41]. Compared to these counties, the progress in Ethiopia is slow.

Although efforts to eradicate IDD in Ethiopia date back to a USI program that was started in 1989, and which had initially reached nearly $80 \%$ of households with iodized salt, the program slowed down drastically in the 2000's due to the Ethio-Eretria war that interrupted access to iodized salt from the red sea [12]. After that, Ethiopia relied on imports from salt producing countries. In 2005, the government of Ethiopia replanned the strategies for the achievement of IDD eradication by the year 2015 through USI strategy. In 2009/ 10 , the government again launched USI initiatives to revitalize and maintain USI distribution throughout the country [42]. It has also passed salt regulation as of March 2011 requiring that salt used for human consumption should be iodized [17, 43]. Interestingly, the government began to explore indigenous salt production sources in response to the border conflict between Ethiopia and Eritrea, and has successfully exploited the 
salt deposits at Lake Afdera in Afar region. Today, about $95 \%$ of the salt consumed in Ethiopia is produced in the country and the salt supply has dramatically shifted by successfully developing new sites in this area to meet the salt needs of the country $[12,16]$. Such development sites have been limited with small scale iodized salt producers in the northern part of the country particularly in Afar (Lake Afdera) and Tirgay region (Mekelle city). Almost all of these producers, however, use non-robust methods of iodization using knapsack manual sprayers which is a low-tech method and the results are uneven. Interestingly, there are few small scale producers that are using advanced technologies, for example, 'Shewitt', a small cooperative, has been successfully conducting salt iodization with an advanced machine and upgraded iodized salt tester which received from the support of GAIN. Concerted efforts and support provided by GAIN, UNICEF and the government have reportedly improved the coverage of salt iodization to reach $\sim 88 \%$ of households [43]. Nevertheless, despite such impressive iodized salt production progress, the country remains on the list of the countries with the highest prevalence of ID and the weakest salt iodization programs [32].

There are two independent reports in Jimma and Metekel zones about household preferences regarding the use of iodized salts. In Jimma, in January 2011, $71.2 \%$ of the households were still using only noniodinated salt, while 26.2 and $2.6 \%$ of households used iodinated salt and both iodinated and non iodinated salt, respectively [7]. Mezgebu et al. evaluated the iodine levels in iodized salt and found that although about $75.0 \%$ of iodinated salt samples were of good quality $>15 \mathrm{ppm}$ iodine level, $25.0 \%$ were inadequate [7]. However, only $10 \%$ of the household salt samples were sufficiently iodized, and 30 and $60 \%$ were insufficiently iodized and non-iodated, respectively, in Metekel zone [32]. Thus, both studies highlighted that the coverage is much below $90 \%$, the recommended value by international organizations. Inadequacy of iodine levels in iodized salts and shortage of iodized salt in households of different areas is likely due to poor iodization technology and the difficulty of sustainable supplying iodine to small-scale salt producers.

Anticipating the renewal of universal salt iodization in 2011, salt iodine content was also assessed in Tigray regions [5]. The mean concentration of iodine in salt at the production site was $57.9 \mathrm{mg} / \mathrm{kg}$ with a maximum and minimum of $98.4 \mathrm{mg} / \mathrm{kg}$ and above $20 \mathrm{mg} / \mathrm{kg}$, respectively. However, such optimum iodine levels fell through the distribution chains, dropping from $57.9 \mathrm{mg} /$ $\mathrm{kg}$ at production to $41.3 \mathrm{mg} / \mathrm{kg}$ at the retailer. From there, iodine content dropped to $25.1 \mathrm{mg} / \mathrm{kg}$ at household level. In other words, on average, the iodine concentration in iodized salt was reduced by $57 \%$ from production site to consumption level. Such loss of more than $50 \%$ iodine could stem from lack of enforcement of the legislation and weak regulation of the producers and retailers. In addition, poor salt handling and storage practices at the retail and household levels are likely obstacles in the implementation of iodized salts intervention [44]. A further problem is that the population, especially in rural areas, may prefer non iodated salt to iodized salt which is more costly. They also assume rock salt tastes better than fine salt, is more compatible with traditional food processing and can be purchased in bulk. Such cultural considerations could also impede the national intervention plan and put the population's health at risk of iodine deficiency. Thus public education and a campaign to raise awareness should be seen as a necessary component to ensure effective implementation of policies intended to eradicate ID.

\section{Factors aggravating ID in Ethiopia}

A number of environmental and dietary factors associated with the availability of iodine affect the prevalence and severity of IDD in iodine deficient areas. The topography of Ethiopia is mountainous and the top layer of the soil has been eroded for decades leading to leaching away of nutrients including iodine [14]. As a result crop cultivation may be close to iodine free. A recent study of the iodine content in water, soil, cereals and table salt in three towns of Bale zone, Oromia region [20] revealed that the concentration of iodine was significantly low in all water samples while other goitrogenic minerals were found in high concentrations. In soil samples in nonfarm lands, iodine concentrations were significantly higher than in regular farming lands, which typically use chemical inputs. Most common cereals cultivated in the area such as wheat and barley samples had significantly low iodine contents. Salt samples in these area contained less iodine concentration than the required amount.

Moreover goitrogenic dietary factors such as cassava, cruciferous vegetables (cabbage and kale), lima beans, linseed, sorghum, sweet potato, etc. must be considered $[24,45]$. Notably, cassava, which plays a dominant role in feeding many people in most tropical developing countries, contains cyanogenic glucosude, a goitrogen that inhibits iodine uptake by the thyroid gland during consumption of unprocessed cassava [46]. The prevalence of IDD in many parts of SNNPR, BenshangulGumuz and some parts of western Oromia region where cassava is a staple food suggests that in these regions the disease may aggravated by diet. Cassava consumption and living in high altitude areas such as Amhara, Oromia, Tigray, SNNPR and Benshangul-Gumuz were found to be high risk factors for IDD [47]. Abuye and colleagues note that in SNNPR and Benshangul-Gumuz, those who consume cassava frequently were significantly affected by 
goiter more frequently than those consuming rarely or not [47].

\section{Challenges and future perspectives}

This review is limited to publically available data found in the scientific literature and reports from the years 2000-2015. It is possible that more recent unpublished data are available to those agencies involved in implementing the National Nutrition Programme. Nevertheless, the studies in this review provide important data on the prevalence of IDD in Ethiopian women and children, which remains high even after the recent implementation of universal salt iodization and strongly support the interventions undertaken in different regions of the country. The few studies that considered iodine levels in salt, water and soil, as well as salt iodide concentrations at the producer, retailer and household levels, provide essential input for the government efforts to improve the distribution and handling of iodized salt. In general, the studies reviewed have the following limitations:

$>$ Almost all of the included studies used a crosssectional design. Although this is appropriate for the relatively quick and cheap assessment of disease prevalence in a population it can only provide a snapshot of the frequency of ID in a population at a given point in time; it can be susceptible to bias due to low-response and misclassification, and it can be difficult to interpret any identified associations [48].

$>$ Most of the studies used limited indicators (UIC and GR) to estimate the prevalence of ID. UIC has been extensively used to assess iodine status of populations. Because of high diurnal and inter day variation in individuals, the use of UIC as a marker for assessing individual status is limited, particularly in the absence of accurate assessment of intake. Although these variations level out when used in large population samples, they do not provide direct information about thyroid function [46]. In utilizing GR, inspection and palpation have traditionally been used to classify goiter. Nevertheless, in areas of mild-to moderate IDDs, the sensitivity and specificity of palpation are poor [36].

$>$ The majority of the studies are limited to a few areas in a very few regional states, and data are missing from other regions and cities which represent a larger proportion of the population.

These limitations notwithstanding, this review identifies following priorities for addressing IDD in Ethiopia:
$>$ Due to limited data available and the deleterious effects of ID on pregnant women and infants, priority should be given to studies of these vulnerable groups.

$>$ Prospective cohort studies should be conducted to assess the severity of IDD in vulnerable groups and to identify those factors that might modify the association between IDD and thyroid disease in this population.

$>$ Data on iodine level and ID status in areas of the major regions where no studies have been conducted to date are crucial for mapping the problem and developing, implementing and monitoring a successful USI strategy.

$>$ Biomarkers of IDD such as blood thyroidstimulating hormone (TSH) and blood thyroglobulin should be used to improve study validity.

$>$ Examination of outcomes other than goiter, such as cognitive effects, language and fine motor function should be conducted in children and mothers.

$>$ Randomized control trials of the impact of iodine supplements should be carried out on cognitive development and intellectual outcomes of school children in Ethiopia.

$>$ Studies are needed to identify ways to prevent the loss of iodine from iodized salt at producers, retailers and household levels.

$>$ Environmental and dietary factors must be addressed as potentially contributing to the severity of IDD in different regions of Ethiopia. As modifying these environmental and cultural-dietary factors will be difficult, education and awareness programs will be important. Raising public awareness of ID could enhance success of USI and might reduce the burden of IDD.

\section{Conclusion}

In conclusion, IDD remains a major public health problem in many parts of Ethiopia. Although iodized salt coverage of $\sim 88 \%$ households is an impressive interim result, this achievement must be expanded by improving manufacturing and distribution processes, and supported by public awareness programs until the goal of universal coverage and a significant reduction in ID is reached. Regular, national monitoring of iodine status, thyroid function and relevant health outcomes will be necessary both to determine if the program has achieved the desired reduction in IDD, and how this has affected health and cognitive measures of women and children. Implementation of these recommendations will improve the health of millions of Ethiopian citizens and serve to inform efforts to eradicate IDD elsewhere. 


\section{Abbreviations}

ENMS: Ethiopia National Micronutrient Survey; ID: iodine deficiency; GR: goiter rate; IDD: iodine deficiency disorder; SNNPR: Southern Nations Nationalities and Peoples Region; TG: total goiter; TGR: total goiter rate; UIC: urinary iodine concentration; USI: universal salt iodization.

\section{Competing interests}

The authors declare that they have no competing interest.

\section{Authors' contributions}

TMG and AMT designed the review, TMG carried it out, TMG and AMT drafted the manuscript and both approved the final manuscript. AMT is the Israeli national representative to the lodine Global Network (formerly ICCIDD) and as co-investigator in the EUthyroid consortium he has received funding from the European Union's Horizon 2020 research and innovation programme under grant agreement No 634453. All authors read and approved the final manuscript.

\section{Acknowledgements}

The authors would like to thank The Mauerberger Foundation Fund (South Africa) and Mrs. Isabelle Adler for their generous scholarship supporting TMG in the International MSc in Nutrition Science at the Hebrew University of Jerusalem.

Received: 29 September 2015 Accepted: 9 February 2016 Published online: 16 February 2016

\section{References}

1. Gunnarsdottir I, Dahl L: lodine intake in human nutrition: a systematic literature review. Food \& Nutrition Research. 2012:56:19731.

2. Hetzel B. lodine-deficiency disorders. 10th ed. London: Churchill Livingstone; 2000.

3. Sharp P. Minerals and trace elements: iodine. 11th ed. London: Elsevier Limited; 2005.

4. Zimmermann M. Are weaning infants at risk of iodine deficiency even in countries with established iodized salt programs? Nestle Nutr Inst Workshop Ser. 2012;70:137-46.

5. Shawel D, Hagos S, Lachat K, Kimanya E, Kolsteren P. Post-production Losses in iodine concentration of salt hamper the control of iodine deficiency disorders: a case study in Northern Ethiopia. J Health Popul Nutr. 2010;28:238-44.

6. Dugassa B. lodine deficiency and women's health: Colonialism's malign effect on health in Oromia region, in Ethiopia. Tor Public Health. 2013; 5:958-72.

7. Mezgebu Z, Mossie A, Rajesh P, Beyene G. Prevalence and severity of iodine deficiency disorder among children 6-12 years of age in Shebe Senbo district, Jimma zone, southwest Ethiopia. Ethiop J Health Sci. 2012;22:196-204.

8. Adish A, Chuko T, Abay A, Assey V, Desta T. Ethiopia: breakingtrough with a new iodized salt law. IDD Newsletter. 2013;39(4):7-8. http://www.ign. newsletter/idd nov13 ethiopia.pdf.

9. Zimmermann M. The effects of iodine deficiency in pregnancy and infancy. Pediatr Perinat Epi. 2012;26:108-17.

10. Andersson M, Karumbunathan $\mathrm{V}$, Zimmermann M. Global iodine status in 2011 and trends over the past decade. J Nutr. 2011;142:744-50

11. Takele L, Belachew T, Bekele T. lodine concenteration in salt at household and retail shop levels in Shebe town, Southwest Ethiopia. E Afr Med J. 2003:80:532-9.

12. ICCIDD. Salt lodization in Ethiopia: New partnerships give children a brighter future. IDD Newsletter 2009;33(3):13-14. http://www.iccidd.org/cm data/IDD-NL-2009-3.pdf.

13. Abuye $C$, Berhan $Y$. The goitre rate, its association with reproductive failure, and the knowledge of iodine deficiency disorders (IDD) among women in Ethiopia: Cross-section community based study. BMC Public Health. 2007;7:316.

14. Delange F. lodine requirements during pregnancy, lactation and the neonatal period and indicators of optimal iodine nutrition. Public Health Nutr. 2007;10:1571-80

15. ICCIDD. Children in Northern Ethiopia are iodine deficient. IDD Newsletter 2014. Available at: http://ign.org/cm_data/idd_may14_ethiopia.pdf.

16. Abuye C, Berhane Y, Akalu G, Getahun Z, Ersumo T. Prevalence of goiter in children 6 to 12 years of age in Ethiopia. Food Nutr Bull. 2007;28:391-8.
17. Ethiopia National Micronutrient Survey (ENMS): National salt iodization coverage towards Prevention of lodine Deficiency Disorder in Ethiopia. In: USI Presentation Forum 2014. Available at: http://www.ephi.gov.et/images/ pictures/USI\%20presentation ForumOctober 25 2014.pdf.

18. Negeri Z, Gobena T, Rajesh P, Kassim M. Determining the magnitude of iodine deficiency and its associated risk factors among pregnant women visiting Jimma University Specialized Hospital for Antenatal Care. World J Med Med Sci. 2014;2:1-16.

19. Abuye C, Urga K. Determinants of iodine deficiency in school children in different regions of Ethiopia. East Afr Med J. 2000;77:133-7.

20. Duressa F, Mohammed Y, Feyissa R, Tufa T, Siraj K. Comparative analysis of iodine concentration in water, soil, cereals and table salt of Horaboka, Mio and Besaso Towns of Bale Robe, South East Ethiopia. J Environ Pollut Human Health. 2014;2:27-33.

21. Kedir H, Berhane $Y$, Worku A. Subclinical iodine deficiency among pregnant women in Haramaya District, Eastern Ethiopia: A Community-Based Study. J Nutr Metab. 2014:2014:8.

22. Berhanu N, Wolde Michael K, Bezabih M. Endemic goiter in school children in Southwestern Ethiopia. Ethiop J Health Dev. 2004:18:175-8.

23. Bogale A, Abebe Y, Stoecker B, Abuye C, Ketema K, Hambidge M. lodine status and cognitive function of women and their five year old children in rural Sidama, Southern Ethiopia. East Afr J Public Health. 2009;6:296-9.

24. Gebreegziabher T, Teyike N, Mulugeta A, Abebe Y, Hambidge K, Stoecker B. Lack of dietary sources of iodine and the prevalence of iodine deficiency in rural women from Sidama zone, Southern Ethiopia. Afr J Food Agric Nutr Dev. 2013:13:8401-14

25. Ersino G, Tadele H, Bogale A, Abuye C, Stoecker B. Clinical assessment of goiter and low urinary iodine concentration depict presence of severe iodine deficiency in pregnant Ethiopian women: a cross-sectional study in rural Sidama, Southern Ethiopia. Ethiop Med J. 2013:51:133-41.

26. Girma M, Loha E, Bogale A, Teyikie N, Abuye C, Stoecker J. lodine deficiency in primary school children and knowledge of iodine deficiency and iodized salt among caretakers in Hawassa Town: Southern Ethiopia. Ethiop J Health Dev. 2012;26:30-5.

27. Wolka E, Shiferaw S, Biadgilign S. The effect of iodine-deficiency disorders on academic achievement of schoolchildren in Southern Ethiopia. Public Health Nutr. 2014;17:1120-4.

28. Wolka E, Shiferaw S, Biadgilign S. Epidemiological study of risk factors for goiter among primary schoolchildren in southern Ethiopia. Food Nutr Bull. 2014;35:20-7.

29. Bezabih B, Assefa Y, Yismaw G, Mulu A. Determination of urinary iodine excretion to assess iodine deficiency level and iodine intake in primary school children, Bahir Dar, Northwest Ethiopia. Ethiop Med J. 2007:45:377-82

30. Kebede A, Adamu B, Girmay A, Yohannes T, Alemnesh Z, Abuye C. lodine deficiency disorders (IDD) in Burie and Womberma Districts, West Gojjam, Ethiopia. Afr J Food Agric Nutr Dev. 2014;14:9167-80.

31. Mesele M, Degu G, Gebrehiwot H. Prevalence and associated factors of goiter among rural children aged 6-12 years old in Northwest Ethiopia, cross -sectional study. BMC Public Health. 2014;14:130.

32. Kibatu G, Nibret E, Gedefaw M. The status of iodine nutrition and iodine deficiency disorders among school children in Metekel zone, Northwest Ethiopia. Ethiop J Health Sci. 2014;24:109-16.

33. Kidane T, Woldegebriel A. Prevalence of lodine deficiency disorder in a highland district in Tigray. Ethiop J Health Dev. 2006;20:58-9.

34. Tsegaye B, Ergete W. Histopathologic pattern of thyroid disease. East Afr Med J. 2004:80:525-8.

35. World Health Organization/United Nations Children's Fund/International Council for control of lodine Deficiency Disorders. Assessment of iodine deficiency disorders and monitoring their elimination. In: A Guide for Program Managers. 3rd ed. Geneva: World Health Organization; 2007.

36. Zimmermann M. Assessing iodine status and monitoring progress of iodized salt programs. J Nutr. 2004;134:1673-7.

37. Zimmermann M, Moretti D, Chaouki N, Torresani T. Introduction of iodized salt to severely iodine deficient children does not provoke thyroid autoimmunity. A one year prospective trial in northern Morocco. Thyroid. 2003;13:199-203.

38. Assey D, Peterson S, Kimboka S, Ngemera D, Mgoba C, Ruhiye M, et al. Tanzania national survey on iodine deficiency: impact after twelve years of salt iodations. BMC Public Health. 2009;9:319.

39. Zhao J, Xu F, Zhang Q, Shang L, Xu A, Ghao Y, et al. Randomized clinical trial comparing different iodine interventions in school children. Public Health Nutr. 1999;2:173-8. 
40. United Nations Standing Committee on Nutrition: Eleventh ECOWAS Nutrition Forum held at Freetown, Sierra Leone. In SCN News Supplement: 2010: ISSN 1564 - 3743. Available at http://www.unscn.org/files/Publications/ SCN_News/Supplement_ECOWAS scnnews38 final.pdf

41. Adejo G, Enemali M. $100 \%$ salt iodization in Nigeria: the lopsided figure. Transnational J Sci Tech. 2013;3:85-91.

42. Ethiopian Federal Ministry of Health/United Nations Children's Fund/ Micronutrient Initiative. The Ethiopian National Salt lodization Launching and Scale-Up program. Addis Ababa: Ethiopian Ministry of Health; 2009.

43. Eliminating lodine Deficiency Disorder in Ethiopia

44. Kulwa M, Kamuzora K, Leo G. Urinary iodine concentration and availability of iodated salt in school children in goiter endemic district of Tanzania. East Afr Med J. 2006;83:79-84

45. Zimmermann M. Geographical and geological influences on nutrition lodine deficiency in industrialized countries. Proc Nutr Soc. 2010;69:133-43.

46. Rohner F, Zimmermann M, Jooste P, Pandav C, Caldwell K, Raghavan R, et al. Biomarkers of nutrition for development-iodine review. J Nutr. 2014;144:1322S-42S.

47. Abuye $C$, Berhane $Y$, Ersumo T. The role of changing diet and altitude on goiter prevalence in five regional states in Ethiopia. East Afr J Public Health. 2008;5:163-8.

48. Mann J. Observational research methods. Research design II: cohort, cross sectional and case-control studies. Emerg Med J. 2003;20:54-60.

\section{Submit your next manuscript to BioMed Central and we will help you at every step:}

- We accept pre-submission inquiries

- Our selector tool helps you to find the most relevant journal

- We provide round the clock customer support

- Convenient online submission

- Thorough peer review

- Inclusion in PubMed and all major indexing services

- Maximum visibility for your research

Submit your manuscript at www.biomedcentral.com/submit 